\title{
Lumbrineris flabellicola (FAGE, 1936), a Lumbrinerid Polychaete Associated with a Japanese Ahermatypic Coral
}

\author{
TOMOYUKI MIURA ${ }^{1)}$ and YosHIHISA SHIRAYAMA ${ }^{21}$ \\ 1)Faculty of Fisheries, Kagoshima University \\ ${ }^{2)}$ Ocean Research Institute, University of Tokyo
}

日本産単体サンゴ上に生息するギボシイソメ科多毛類

Lumbrineris flabellicola の記録

三浦 知 之・白山義 久

\begin{abstract}
MIURA, TOMOYUKI (Faculty of Fisheries, Kagoshima University) and YoshIHISA SHIRAYAMA (Ocean Research Institute, University of Tokyo). 1992. Lumbrineris flabellicola (FAGE, 1936), a Lumbrinerid Polychaete Associated with a Japanese Ahermatypic Coral. Benthos Research, 43 : 23-27.

Living specimens of the lumbrinerid polychaete Lumbrineris flabellicola (FAGE, 1936) were firstly collected from Japanese water, Southwest off Shikoku Island at depths of 277-317 m. The species lived in a mucous tube attached to the ahermatypic coral Caryophyllia decapali (YABE \& EGUCHI, 1942). The morphological characters of the polychaete were briefly reported.
\end{abstract}

Lumbrineris flabellicola (FAGE, 1936) (Lumbrineridae, Polychaeta) has been recorded from Japan only in a literature in which the scars of their mucous tubes have been photographed on a specimen of Flabellum pavoninum from Sagami Bay (as F. disjuncta by YABE \& EGUCHI, 1942, Pl. 7, Fig. 7), and no living specimen has been collected so far (ZIBROWIUS et al., 1975). During the cruise KT-8616 of R/V "Tansei-Maru", 13 living specimens of this polychaete were captured from Southwest off Shikoku Island at depths of $277-317 \mathrm{~m}$. We could also examine a batch of specimens sent by courtesy of Dr. H.ZIBROWIUS of the University of Aix-

Received May 20, 1991 : Accepted Septmber 27, 1991
Marseille 2. In this study, the occurrence of this lumbrinerid polychaete is reported with a short note on morphological characters and figures. We deeply thank Dr. H. ZIBRowius who kindly idenified the host corals and provided us valuable information as well as a part of specimens examined in this study. We are also indebted to two anonymous reviewers for their critical reading of the manuscript and giving us many valuable comments.

Lumbrineris BLAIN VILLE, 1828

Lumbrineris flabellicola (FAGE, 1936)

(Figs. 1-3)

Lumbriconereis flabellicola FAGE, 1936, pp. 941-944,

figs. $1 \& 2$. 
Lumbrineris flabellicola ZIBROwIUs et al., 1975, pp. 84-89, fig. 1, pls. 1-5.

Material examined. Pacific Ocean, (Japan) off Ashizuri Misaki, SW of Shikoku Island, R/V "Tansei-Maru" Cruise KT-86-16 Station B-6, 1 Nov., $1986,32^{\circ} 35.8^{\prime} \mathrm{N}, 132^{\circ} 42.6^{\prime} \mathrm{E}, 277-286 \mathrm{~m}, 1 \mathrm{~m}$ ORI Biological Dredge, associated with Caryophyl lia decapali, 12 specimens: off Okinoshima Island, SW of Shikoku Island, KT-86-16 Station A-2, 31 Oct., $1986,32^{\circ} 40.8^{\prime} \mathrm{N}, 132^{\circ} 28.1^{\prime} \mathrm{E}, 306^{-3} 17 \mathrm{~m}, 1 \mathrm{~m}$ ORI Biological Dredge, associated with $C$. decapali, 1 specimen: (Phillipines), R/V "Suroit" Cruise MUSORSTOM 2 Station 33, 13 32.3'N, $121^{\circ} 07.5^{\prime} \mathrm{E}$, 130-137 m, 24 Nov., 1980, associated with Balanophyllia sp., I specimen: Cruise MUSORSTOM 2
Station 63, $14^{\circ} 07.3^{\prime} \mathrm{N}, 120^{\circ} 15.0^{\prime} \mathrm{E} 215^{-230} \mathrm{~m}, 29$ Nov., 1980, associated with Acanthocyathus spinicarens and $A$. spiniger, 2 specimens.

Atlantic Ocean, Galice Bank, R/V "Noroit" Cruise SEAMOUNT Station DW 116, 20 Oct., 1987, $42^{\circ} 52$. $4^{\prime}$ 'N, $11^{\circ} 50.6$ 'W, 985-1000 m, associated with Desmophyllum cristagalli, 3 specimens and 1 posterior fragment: Gorringe Bank, SEAMOUNT Station DW 8, 22 Sep. 1987, 36 28.5'N, 11 37.1'W, 470-485 m, associated with Flabellum chunii, 1 specimen: Gorringe Bank, SEAMOUNT Station CP 11, 23 Sep. $1987,36^{\circ} 26.4^{\prime} \mathrm{N}, 11^{\circ} 40.2^{\prime} \mathrm{W}, 805-830 \mathrm{~m}$, associated with Flabellum chunii, 1 specimen: off Morocco, R/V "Cryos" Cruise BALGIM Station $157,36^{\circ} 21.0^{\prime} \mathrm{N}, 7^{\circ} 55.8^{\prime} \mathrm{W}, 1108 \mathrm{~m}, 18$ Jun., 1984, as-
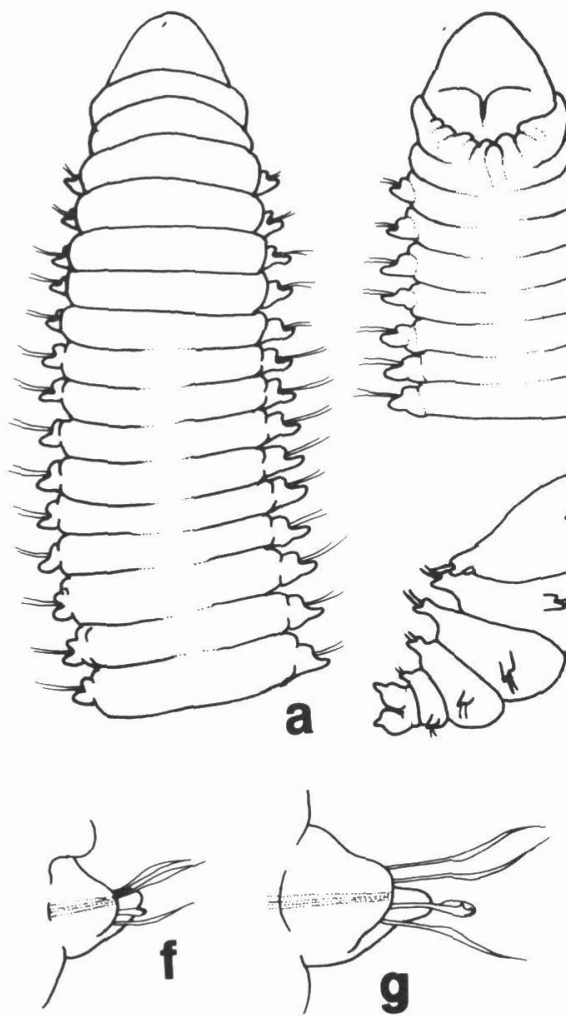

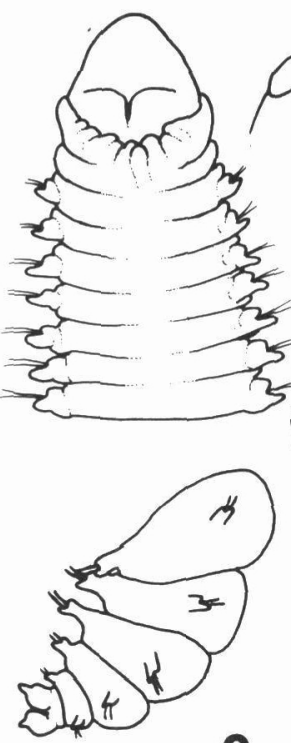

c

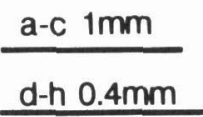

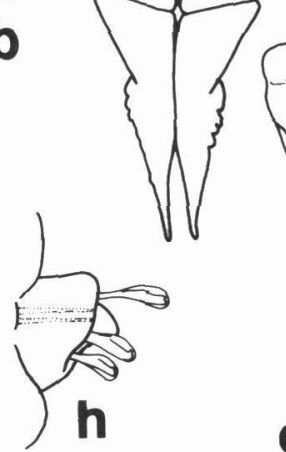
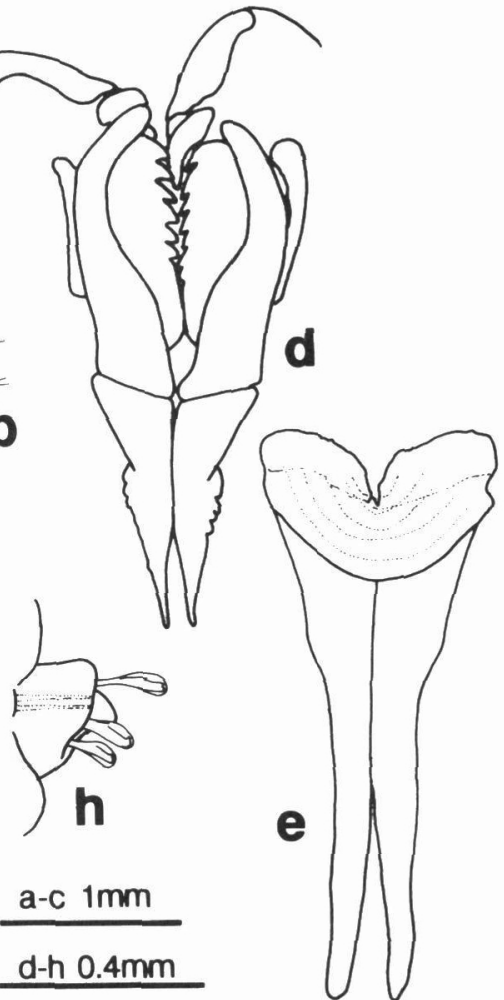

Fig. 1 Lumbrineris flabellicola (FAGE, 1936) drawn from Japanese complete specimens. a: Anterior end, dorsal view, b: Same, ventral view, c: Posterior end, ventral view, d: Maxillae, dorsal view, e: Mandibles, ventral view, f: Parapodium 1, anterior view, g: Parapodium 5, anterior view, h: Parapodium 20, anterior view. 
sociated with Balanophyllia cellulosa, 1 specimen: NW Bank of Ivis, R/V "Suroit" Cruise BENTHEDI Station 77F, $12^{\circ} 34.2^{\prime} \mathrm{S}, 44^{\circ} 54.0^{\prime} \mathrm{W}, 480-530 \mathrm{~m}, 31$ Mar., 1977, associated with an unidentified scleractinian coral, 1 specimen.

Indian Ocean R/V "Anton Bruun" Cruise 7 Station 390S, 9 Sep., $1964,29^{\circ} 35^{\prime} \mathrm{S}, 31^{\circ} 42^{\prime} \mathrm{E}, 138 \mathrm{~m}$, associated with Flabellum pavoninum ?, 2 fragments (USNM 257911): Kenya coast, N of Mombasa, Cruise 8 Station 421 G, Nov., 1964, 29 35'S, 31 42'E, $138 \mathrm{~m}$, associated with Flabellum pavoninum ?, 1 specimen and 1 fragment (USNM 323383).

Measurement. Complete ovigerous specimen from Japan measuring $21 \mathrm{~mm}$ long by $1.5 \mathrm{~mm}$ wide including parapodia with 52 setigers. Other complete Japanese specimens measuring 17-26 mm long by $1.3-1.8 \mathrm{~mm}$ wide with $49-67$ setigers.

Morphological characters. Specimens in alcohol pale with slight iridescence. Body slightly broader than height with arched dorsum and flattened ventrum. Prostomium bluntly conical (Fig. 1a, b). Pygidium with a pair of short anal cirri (Fig. 1c). Parapodia with short presetal lobes and longer conical postsetal lobes (Fig. 1f, g) ; posterior parapodia with slightly shorter postsetal lobes (Fig. 1h). In each parapodium, two to three acicula present. Winged capillary setae present in first 15 -23 setigers in Japanese specimens and in 26 setigers in larger Atlantic specimen; occurring two to three per parapodium on setigers 1-11 and only one thereafter. Simple hooded hooks present on all parapodia, occurring singly on first 11 setigers and two to three thereafter. Hooks with a single enlarged basal tooth and six to seven smaller teeth; basal tooth subdivided terminally in two to six denticles (Fig. 2a, b). Maxillary plates whitish with dark teeth on borders. Maxillae I falcate; Maxillae II with 5-6 teeth on left, 6-7 on right ; Maxillae III with single tooth extending ventrally as dark, broad posterior border; Maxillae IV with dark, conical tooth (Fig. 1d). Mandibles slender, trans. lucent with well-calcified flared distal plate (Fig.
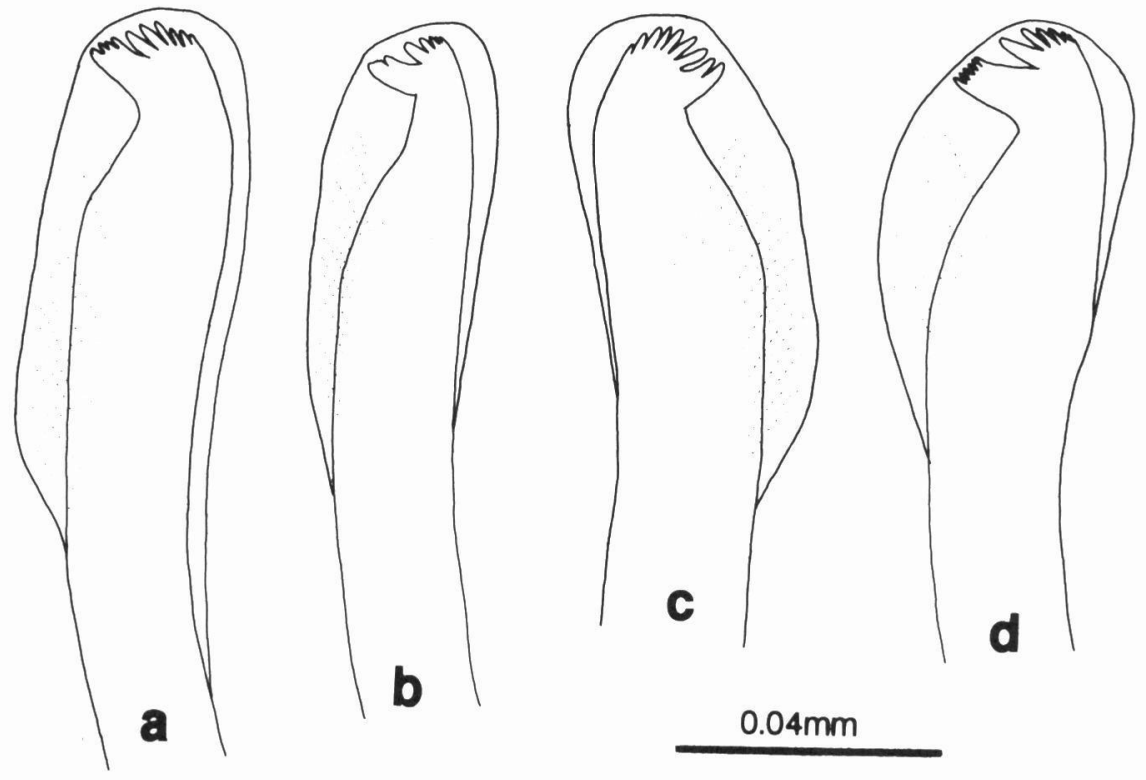

Fig. 2 Simple hooded hooks of Lumbrineris flabellicola (FAGE, 1936). a : On parapodium 15 of a specimen from Japan, b: On parapodium 40 of the same, c: On parapodium 10 of a larger specimen from Galice Bank (SEAMOUNT Station DW 116), d: On parapodium 57 of the same. 

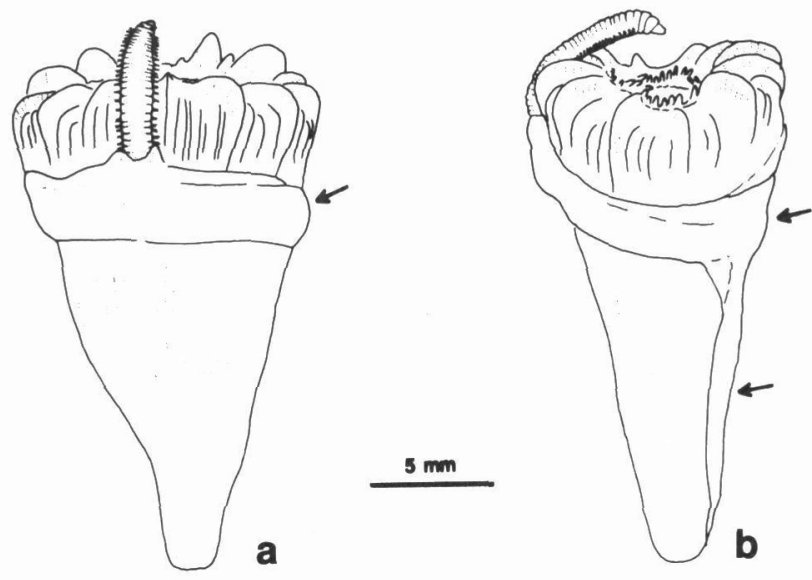

Fig. 3 Lumbrineris flabellicola (FAGE, 1936) on the host coral, Caryophyllia decapali (YABE \& EGUCHI, 1942) from Japan. a: Drawing from the dorsal side of the polychaete, $b$ : Side view of the same, arrows: Mucous tube of the polychaete.

1e).

Mucous, membranous tube attached around coral corallum; sometimes posterior end reaching to coral base (Fig. 3a, b).

Remarks. The affinities of Lumbrineris flabellicola have been discussed extensively by ZIBROWIUS et al. (1975). To date, L. flabellicola is the only species of the genus known to be commensal with or parasitic on ahermatypic corals.

The specimens from various areas including Japan were well identical with this species in main morphological characters, though a minor difference was recognized in the distribution pattern of winged capillary setae. In Japanese specimens, the setae were present on anterior 15-23 setigers, but on 26 setigers in a specimen of $2 \mathrm{~mm}$ wide from Gorringe Bank or on more setigers in the previous descriptions (on anterior 28 setigers in the holotype measuring $55 \mathrm{~mm}$ long with 130 setigers in FAGE, 1936 ; on 40 setigers in ZiBRowiUs et al., 1975). This character may vary due to the size of specimen.

An additional small papilla on the inner base of one or each anal cirrus was observed in two
Japanese specimens, while it was absent in the six remaining Japanese complete specimens and in a fragmental specimen from Galice Bank. This papilla may be an abnormal state of the enflated base of anal cirrus.

\section{References}

FAGE, L., 1936. Sur l'association d'un annélide polychète Lumbriconereis flabellicola $\mathrm{n}$. sp. et d'un madrépore Flabellum pavoninum distinctum E.

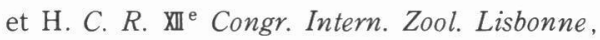
1935 : 941-945.

YABE, H. and M. EGUCHI, 1942. Fossil and recent Flabellum from Japan. Sci. Rep. Tohoku Imp. Univ., Ser. 2, Geol., 22 : 87-103, pls. 5-8.

Zibrowius, H., E. C. Southward and J. H. Day, 1975. New observations on a little-known species of Lumbrineris (Polychaeta) living on various cnidarians, with notes on its recent and fossil scleractinian hosts. J. Mar. Biol. Ass. U. K., $55: 83-108$.

\section{和文摘要}

淡青丸航海 “KT-86-16”において単体サンゴ Caryo- 
phyllia decapali (YABE \& EGUCHI, 1942) に粘膜の 管を作って付着するギボシイソメ科多毛類 Lumbrineris flabellicola（FAGE, 1936）を採集した。従来, この多毛類は, ホストの殸表に窪みとして残る生痕だ けが相模湾産の単体サンコから記録されていた。しか し, 本研究により, 日本沿岸での生息がはじめて確認 された。同定にあたっては, 四国南西海域の水深 $277 \sim 317 \mathrm{~m}$ の 2 地点の採集標本および太平洋の他海
域, 大西洋,インド洋の標本とこれまでの記載との比 較を行ったが，主要な形態においては区別できなかっ た。

\section{TOMOYUKI MIURA}

Faculty of Fisheries, Kagoshima University 4-50-20, Shimoarata, Kagoshima 890, Japan 